УДК 625.12

\title{
БІОЛОГІЧНІ ТИПИ КОНСТРУКЦІЙ УКРІПЛЕННЯ УКОСІВ ЗЕМЛЯНОГО ПОЛОТНА ЗАЛІЗНИЦЬ
}

А.О. Лютий

\section{БИОЛОГИЧЕСКИЕ ТИПЫ КОНСТРУКЦИЙ УКРЕПЛЕНИЯ ОТКОСОВ ЗЕМЛЯНОГО ПОЛОТНА ЖЕЛЕЗНЫХ ДОРОГ}

А.О. Лютий

\section{BIOLOGICAL TYPES OF RAILWAY SUBGRADE SLOPE STRENGTHENING CONSTRUCTIONS}

A.O. Lutiy

Наведено класифікацію засобів укріплення конусів $і$ укосів земляного полотна на залізницях. Розглянуто біологічні конструкиії укріплення конусів і укосів земляного полотна, визначено галузі їх застосування. Дано рекомендації щуодо вибору раціональної технології укріплення.

Ключові слова: будівництво $i$ реконструкція залізниць, земляне полотно, укоси земляного полотна, конуси мостів, укріплення укосів і конусів.

Приведена классификаџия средств укрепления конусов и откосов земляного полотна железных дорог. Рассмотрены биологические конструкиии укрепления конусов и откосов земляного полотна, определены области их применения. Даны рекомендации по выбору рачиональной технологии укрепления.

Ключевые слова: строчтельство и реконструкция железных дорог, земляное полотно, откосы земляного полотна, конусы мостов, укрепления откосов и конусов.

Classification of means of railway subgrade cones and slopes strengthening is given. Biological railway subgrade cones and slopes strengthening constructions are considered, scopes of their application are determined. Recommendations for the rational strengthening technology choice are given.

Keywords: construction and reconstruction of railroad roadbed, slopes of roadbed, bridges cones and consolidation of slopes and cones.

Залізниці у пересіченій місцевості проходять в насипах і виїмках. Залежно від кліматичної зони, в якій будується дорога, ступеня пересіченості місцевості і категорії дороги площа поверхні укосів може становити від 180 до 3200 тис. м² на 100 км траси.

Для захисту поверхні укосів від порушень місцевої стійкості розроблено більше 20 видів конструкцій укріплень, частину яких виконують вручну (дернування і т.п.).

Відповідно до загальної класифікації всі конструкції укріплень укосів залежно від їх реакції на зовнішні силові і погоднокліматичні дії можуть бути розділені на три групи:

I група - біологічні типи конструкцій укріплень, призначені для захисту укосів від ерозії, спливів, опливин в районах зі 
сприятливими грунтовими і кліматичними умовами;

II група - несучі конструкції, призначені для компенсації зсувних зусиль, що виникають у грунті поверхневих шарів укосів, а також силових дій паводкових i поверхневих вод;

III група - захисні й ізолюючі конструкції, призначення яких - ізолювати поверхневі шари укосу від температурних впливів, вбирати атмосферні опади i відводити грунтові води.

Конструкції I групи рекомендується застосовувати як основний тип укріплення для захисту укосів насипів, які не підтоплюються, сухих (нескельних) виїмок y сприятливих кліматичних i грунтових умовах, а також насипів, які підтоплюються, при швидкості течії менше 0,6 м/с і відсутності хвиль або в окремих зонах підтоплення.

Дерновий покрив слід використовувати для укріплення укосів тільки при його наявності у безпосередній близькості від об'єкта будівництва, у разі економічної доцільності.

У даній статті розглядаються біологічні типи конструкцій укріплення укосів земляного полотна залізниць.

Біологічні типи конструкцій укріплення укосів включають дернування, сіяння трав різними методами, садіння чагарнику, плотові проростаючі укріплення, проростаючі вистілки, фашинні конструкції.

Суцільне дернування застосовують для укріплення укосів із глинистих i суглинних грунтів, а також насипів, які підтоплюються, при швидкості течії менше $0,6 \mathrm{~m} / \mathrm{c}$ i відсутності хвиль. Для виготовлення 1000 шт. спиць при довжині $20 \mathrm{~cm}$ необхідно $0,15 \mathrm{~m}^{3} \quad$ обрізків лісоматеріалів, при довжині $30 \mathrm{~cm}-0,25 \mathrm{~m}^{3}$.

Дернування стінкою міцніше за суцільне дернування і застосовується для укріплення укосів, які підтоплюються, при швидкості течії до 1,5 м/с і висоті хвилі не більше 0,6 м, а також при необхідності збільшити крутість укосів при будівництві залізниць в стислих умовах.
Дерен в цьому випадку укладають горизонтальними або похилими до укосу рядами при його крутості 1:1. Дернини укладають травою донизу за винятком останнього верхнього ряду, який укладають травою догори. Витрата дерну на $1 \mathrm{~m}^{2}$ поверхні укосу становить не менше 2023 шт. дернин.

Дернування клітинкою застосовують для захисту укосів від розвитку ерозійних деформацій.

Для улаштування клітинок застосовують дернові стрічки шириною 0,25 м, довжиною 2-3 м або штучні дернини розміром $20 \times 30$ і $30 \times 50$ см при товщині дерну 6-10 см. Дернові стрічки укладають на поверхні укосу по двох взаємно перпендикулярних напрямках під кутом $45^{\circ}$ до твірної укосу.

Чарунки розміром не більше $1,5 \times 1,5 \mathrm{~m}$ заповнюють рослинним грунтом урівень 3 дерновою стрічкою і засівають насінням трав (наприклад, методом гідросіяння). В умовах вологого клімату при заповненні чарунок рослинним грунтом, багатим гумусом, і хорошій якості дерну, чарунки між дерновими стрічками (розміром не більше $1 \times 1$ м) можна не засівати.

Уздовж брівки укосу укладають одну суцільну дернову стрічку; підошва укосу має бути укріплена суцільними дерновими стрічками в 3 ряди. Нижню дернову стрічку слід врізати в грунт основи на $1 \mathrm{~m}$ i закладати місцевим грунтом, ретельно утрамбувавши врівень 3 поверхнею землі. При піщаних грунтах, а також жирних глинах перед улаштуванням дернування клітинкою необхідно укладати рослинний грунт шаром не менше 0,1 м або добре розкладений торф товщиною $0,1 \mathrm{M}$ (за наявності торфів у районі робіт).

Дерновий покрив на укосах можна створювати двома способами:

-механізованим сіянням трав по завчасно нанесеному на укоси земляного полотна рослинному грунту шаром 10-15 cм 3 вмістом гумусу не менше 2\%; 
-гідросіянням багаторічних трав 3 мульчуванням. При цьому способі природну поверхню укосів земляного полотна покривають сумішшю спеціального складу, до якої входять насіння трав, мінеральні добрива, мульчувальний та плівкотвірний матеріали і вода.

Укоси засівають багаторічними (від двох до восьми років і більше) злаковими і бобовими травами, самопоновлення яких дозволяє отримати постійний трав'яний покрив на поверхні укосів. Рекомендуються такі трикомпонентні суміші трав, \%: кореневищні злакові трави - 35-55; пухкокущові злакові трави - 30-50 (менші величини в обох випадках - для легких грунтів, більші - для важких зв'язних грунтів); стрижнекореневі бобові трави 5-20 (для лісової зони 5-10, для степової - 15-20).

При укріпленні укосів сіянням трав по рослинному грунту на $100 \mathrm{M}^{2}$ площі рекомендується застосовувати добрива в такій кількості, кг: фосфорні - 3, азотні - 2, калійні - 2.

Для гідросіяння норму азотних добрив збільшують до 6 кг на $100 \mathrm{~m}^{2}$.

Як мульчувальні матеріали рекомендується використовувати тирсу або торфокришку, просіяні через сито 3 чарунками $10 \times 10 \mathrm{~cm}$, а також нарубану солому довжиною 3-4 см.

Витрата мульчувальних матеріалів на $1000 \mathrm{~m}^{2}$ поверхні, яка укріплюється, становить, кг: тирси - 400 , соломи - 200, бітумної емульсії - 1 , води -5 , латексу (сухої речовини) - 40, добрив (суміш азотних, фосфорних і калійних) - 50-80.

Як плівкотвірні матеріали при гідросіянні рекомендуються синтетичні латекси марок СКС-65ГП, СКС-60ГП, СНК-40ПН або швидко- і середньорозпадні дорожні бітумні емульсії прямого типу.

Суцільне садіння чагарнику призначене для захисту укосів крутістю не більше $1: 1,5$, складених глинистими грунтами, від розвитку деформацій локального ковзання, пластичної течії, поверхневих спливів і опливин. Чагарник повинен мати густу наземну поросль i потужну кореневу систему. Для укріплення укосів від неглибоких спливів рекомендується садіння місцевих порід чагарникових верб живцями, кілками та прутами.

Плотові проростаючі укріплення застосовують у тих випадках, коли живцевого садіння виявляється недостатньо для забезпечення місцевої стійкості укосів, зокрема складених глинистими грунтами, схильними до спливоутворень. Проростаючі плотові конструкції 3 усіх біологічних типів найбільш стійкі проти розмиваючої дії потоків, які утворюються в результаті інтенсивних злив або сніготанення. Для плотових укріплень застосовують кілки і батоги, здатні до проростання. Кілки довжиною $1 \mathrm{~m}$, товщиною в окоренку 0,04-0,05 м і прути довжиною не більше 2 м, товщиною в окоренку 0,03-0,04 м поміщають в канаву глибиною 0,5-0,6 м, шириною по верху 0,5 м, по дну 0,3 м. На дно канави встановлюють тин 3 похилим зашморгуванням 3 проростаючих прутів. Кінці кілків і прутів випускають назовні, при цьому прути повинні підніматися над кінцями кілків на 0,3-0,4 м. Канаву і тин засипають рослинним грунтом i утрамбовують.

Мінімальна відстань між тинами 2 м, у виняткових випадках - 1,5 м. Для економії посадковий матеріал можна висаджувати стрічками шириною 0,7-0,8 м або стрічками, які перехрещуються, що забезпечує стійкість конструкцій укріплення на укосі.

Вистилання (тимчасовий тип укріплення) застосовують у комбінації 3 посадками у випадках, коли до проростання трави або посадок чагарнику укіс не можна залишати без укріплення. Гілки, здатні до проростання, укладають на поверхні укосу рівномірним шаром товщиною 0,2 - 0,3 м окоренками донизу. В укосі роблять поздовжні уступи, на які укладають 
окоренки гілок i засипають рослинним грунтом товщиною 0,1 м. При значній довжині укосу (рахуючи по його твірній) вистілку влаштовують у кілька рядів: спочатку укладають верхній ряд з напуском на раніше покладений ряд приблизно на одну третину середньої довжини гілок, потім так само всі наступні. Гілки закріпляють рядами тонких жердин, які прикріплюють до укосу дерев'яними кілочками. Жердини укладають на відстані 0,5 м від окоренків, відстань між жердинами - не більше $1 \mathrm{~m}$.

Фашинні конструкції призначені для захисту укосів від ерозійних деформацій, деформацій локального ковзання, пластичної течії, спливів і опливин у тих випадках, коли немає інших місцевих недорогих матеріалів.

Фашини виготовляють 3 гнучкого свіжорубаного чагарнику (верби або подібних їй порід), очищеного від листя і тонких гілок, діаметром в окоренку 0,02-0,03 м і довжиною 2,0-4,5 м. Перев'язують фашини дротом або просмоленою мотузкою в середньому через 1 м, на відстані 0,8-0,9 м від кінців фашини.

За способом виготовлення фашини діляться на легкі (тільки 3 дрібного чагарнику) і важкі (заповнені каменем). Чагарниковий матеріал укладають у фашини або окоренками в один бік (однобічні фашини), або в різні боки (двобічні). Фашини обох видів мають товщину 0,25-0,30 м. Довжина двосторонніх фашин досягає 4 м.

Фашини укладають плиском, вигляді матраців, паралельно до твірної укосу або перпендикулярно до укосу, прикріплюючи їх вербовими кілками, здатними до швидкого проростання.

Технологію і засоби механізації для створення вищенаведених типів конструкцій укріплення укосів земляного полотна необхідно призначати 3 урахуванням конструктивних особливостей укосів, типу земляного полотна (насип, виїмка), інженерно-геологічних, гідрометеорологічних та погоднокліматичних умов району будівництва.

Призначати раціональну технологію, а також вибирати засоби механізації слід в залежності від запроектованих конструкцій укріплення укосів і співвідношення їх типів протягом усієї ділянки укріпних робіт, обгрунтувавши такий вибір технікоекономічними розрахунками.

\section{Список використаних джерел}

1. Проектирование земляного полотна железных дорог колеи 1520 мм [Текст]: СП 32-104-98 / Госстрой России. - М.: ЦНИИС, 1999.

2. Методические рекомендации по выбору конструкций укрепления конусов и откосов земляного полотна, технологии и механизации укрепительных работ [Текст] / Союздорнии. M., 1981.

Лютий Артем Олегович, слухач ІППК.

Lutiy A.O. 